SCHOLARS: Journal of Arts \& Humanities

[Peer-Reviewed, Open Access, Indexed in NepJOL]

Central Department of English

Print ISSN: 2773-7829; e-ISSN: 2773-7837

Volume 1, August 2019, pp. 79-90

Tribhuvan University

DOI: https://doi.org/10.3126/sjah.v1i0.34450

Kirtipur, Kathmandu, Nepal

www.cdetu.edu.np/ejournal/

\title{
Law and Literature: A Review of Interdisciplinary Literary Texts
}

\author{
Raj Kishor Singh, PhD \\ Central Department of English \\ Tribhuvan Univeristy, Kirtipur, Nepal
}

\begin{abstract}
This paper explores and recognizes common points of intersection of law and literature. Different literary texts have legal language, court scenes, cross examinations, lawyers, witnesses, judge, and audience. The main focus of this paper is to identify such events from literary texts and also to present instances that people take into the courts from literary texts. Law and literature originate and develop, after all, from the same culture and society. Humanities and social sciences are common grounds of origin and development of law and literature. They are related with each other. They do have correlation on the basis of culture, social norms and values, and humanities. In this paper, they discussed on the grounds of cognitive and behaviouristic aspects of human life.
\end{abstract}

Keywords: Interdisciplinarity, law and literature, culture and society, literary texts

\section{Introduction}

Law needs to be humane and it serves common people. Law is made for common good. It gets all norms and values from culture. Law, formed in one place, may not be applied in another place. Many norms and values like right or wrong, justice, goodness, fairness, guilt, morality, and other norms and values are not defined within the law itself. Law gets all these from literature because literature is a source of schema or collective understandings of all these things. The formation of law depends on context-time, place, and historical references. For instance, slavery was legal in the past but that is illegal now. Slavery as referred in Stowe's Uncle Tom's Cabin was legal in the past but that is illegal since Proclamation of Emancipation. Heather Lee Cooper writes in his $\mathrm{PhD}$ dissertation about this legality and illegality of slavery (Cooper 1-4). 
Law and Literature: A Review of Interdisciplinary Literary Texts 80

Literary texts have a lot of legal issues, cases, cross examinations, lawyers, clients etc. Shakespeare, Charles Dickens, Leo Tolstoy, Thomas De Quincey, Philip Massinger, and several other writers present legal trials in their works. Dostoevsky's The Brothers Karamazov has a legal trial in the end. Shakespeare's Merchant of Venice has a popular courtroom event with the issue of 'a pound of flesh'. Many literary texts have real stories of courtroom cases. Harper Lee's To Kill a Mockingbird, Paul Thomas Murphy's Pretty Jane and the Viper of Kidbrooke Lane, Arwen Bicknell's Justice and Vengeance, Paul Collins's The Murder of the Century and many other novels have real courtroom stories. "The law hath not been dead,/though it hath slept" (Meaure for Measure, 2.2. line 116-118) in literature.

Literature is source of everything and all knowledge. The textual sources of law in Hindu culture are the Vedas, the post-Vedic literature, the Dharmasastras, and the Epics. The Epics are the Mahabharata, the Ramayana, and SrimadBhagavadgita. The Dharmasastras are Smritis of Manu, Yajnavalkya, Visnu, Narada, Brihaspati, and Katyana. The Arthasastra of Kautilya, the Kamasutra of Vatsyayana, the Mahakavyas, and the Sanskrit classical literature, prominently from the pen of Bhasa, Kalidas, Sudraka, and Visakhadatta are also sources of law in Hindu culture (Sharma 2.1-72).

Francis Bacon's New Atlantis presents a vision of the future of human discovery and knowledge. The book shows many aspirations and ideals for the mankind. Many novels, like H. G. Wells's The World Set Free, E. M. Forster's The Machine Stops, Ernest Callenbach's Ecotopia, and other novels predict future of the world. The World Set Free predicts production of more destructive and uncontrollable weapons in the world. The world has seen such weapons and still expects much more terrible than those weapons. The Machine Stops makes predictions for the technologies like internet and instant messaging. Ecotopia deals with environment and greenery that the mankind has been much worried about.

\section{Law in Literature}

Literature is a very reliable source of formation or enactment of laws. Literary texts are sources for origin and development of laws in the world. Narratives give meaning to laws in the world in which we live. Laws and narratives are not separable. Every generation has some effect upon writers and their works. Legal developments had much influence on the nineteenth century's writers like Charles Dickens. We can read a lot of narratives from his novels with legal contents. Laws are concerned with real-life decisions relating to issues such as the implementation and enforcement of the law, conviction, acquittal, the award of compensation and the sanctioning of punishment (Little 6). Richard Weisberg 
Law and Literature: A Review of Interdisciplinary Literary Texts 81 argues that an appreciation of the ethical and philosophical content of literature has a crucial role in helping lawyers to understand what they do. He further says that the historical literary developments can, from a legal perspective, be viewed as peripheral cultural by-products of legal history (72).

Richard A. Posner discusses in his book Law and Literature that works of literature are about law. The book deals with the body of literature that contains many of the monuments of Western culture, including works of Homer, the Greek tragedians, Shakespeare, Dostoevsky, Melville, and Camus, as well as works of innumerable writers of popular fiction (21). Posner says that, like Forster's novel Howards End, works of literature that do not deal overtly with law can sometimes be better understood by being approached from a jurisprudential perspective (22).

Under the topic "Introduction to Law and Literature: Walking the Boundary with Robert Frost and the Supreme Court," Kieran Dolin, in his book Law and Literature, mentions a case of 1995, in which 'Plaut and Spenthrift Farm Inc.' became a case between the judiciary and Congress, both challenging each other for authority. The judges had taken Robert Frost's poem “Mending Wall” as a resource for discussion over the issue. Dolin writes that this legal story acquires a distinctly literary element in the judgments of the Supreme Court. He further mentions that writing the opinion of the majority of the Court, Justice Antonin Scalia concluded his account of the legal authorities with a summary that relied equally on literary metaphor and logic: "In its major features ... [separation of powers] is a prophylactic device, establishing high walls and clear distinctions because low walls and vague distinctions will not be judicially defensible in the heat of interbranch conflict” (2). Dolin explains, In expounding legal principle and justifying his decision, Justice Scalia employs the rhetorical tools of metaphor and narrative. His metaphor of the wall represents the judicial power in the Constitution as a fortified city under assault from a hostile Congress or Executive. His exposition of the law rests on an implied, imagined narrative of battle. There is nothing extraordinary about Scalia's procedure here: this is a normal instance of judicial reasoning in a run-of-the-mill case. Judges and lawyers routinely seek to clarify theirpronouncements and arguments about the law by resorting to metaphors and stories. They do so because law is inevitably a matter of language. The law can only be articulated in words. While the order of a court will be imposed on the body or the property of the parties to the case, it will originally have been spoken as a sentence. This is the fundamental connection between law and literature. (2) 
Law and Literature: A Review of Interdisciplinary Literary Texts 82

Dolin argues that some judges agreed but qualified their statements. Justice Stephen Breyer questioned their understanding of Robert Frost's poem. He cautioned against "the unnecessary building of such walls" as "in itself dangerous, because the Constitution blends, as well as separates, powers in its efforts to create a government that will work for, as well as protect the liberties of, its citizens" (3). Dolin says that, while refining the meaning of "separation of powers," Breyer also takes the issue with the majority's use of Robert Frost's poem to bolster their decision: "One might consider as well that poet's caution, for he not only notes that 'Something there is that doesn't love a wall,' but he also writes, 'Before I built a wall I'd ask to know / What I was walling in or walling out'” (3). The poet's belief in walls is not as clear-cut as Justice Scalia believed (3). Agreed or disagreed, they have recognized the importance of the literature in legal areas.

\section{Law, Literature and Interdisciplinarity: Discussion}

Elizabeth Villiers Gemmette’s book Law in Literature, published in 2017, covers different volumes with subtitles - legal themes in drama, legal themes in novellas, legal themes in short stories, etc. Some of the common themes in dramas, novels, novellas, and short stories that involve law and legal activities mentioned in Gemmette's books are discrimination and equality, themes related to jurisprudence, related to children, crimes, domestic relations, trials, politics, war, ethics, etc. In the following sections, some of the works in fiction and plays of major writers are discussed with focus on legal scenarios and their significance in literature.

\section{Legal Scenareo in Lewis Carroll's Fiction}

Lewis Carroll's Alice's Adventures in Wonderland has a court scene in the end. Alice is in her final adventure in Wonderland. Someone has stolen the queen's tarts, and the king's court is engaged in cross-examination of witnesses. Alice was first time in a court of justice. She wishes to experience the court's procedurals by herself. The king was the judge in the court. He was sitting there with his crown over the wig. There was also a jury-box. They were making a list of witnesses before the trial. The king is repeatedly asking for evidence during the cross-examination. Alice is growing larger and getting much bolder while sitting in the court during the trial. In spite of warning from the Dormouse that she has "no right to grow here", in that court of justice, Alice does not care and rather challenges the law and system, and she decides to stay there. This closing scene suggests dramatization of what was to become an increasingly popular Victorian scene: a woman questioning and critiquing the law and claiming a place for herself within its institutions. The first half of Queen Victoria's reign witnessed Caroline Norton agitating for a mother's right to custody of her children and making inroads into a 
Law and Literature: A Review of Interdisciplinary Literary Texts 83 father's absolute rights with passage of the Infant Custody Act of 1839 (Kalsem 221). As the judge, the king makes a rule - Rule Forty-two, but Alice disregards it:

At this moment the King, who had been for some time busily writing in his note-book, called out “ Silence!”, and read out from his book,

"Rule Forty-two. All persons more than a mile high to leave the court."

Everybody looked at Alice.

"I'm not a mile high," said Alice.

"You are," said the King.

"Nearly two miles high," added the Queen. (221)

Mother wanted to have rights over her children to keep them in custody. The Infant Custody Act of 1873 was issued for the change in such attitude of parents. It changed the direction of the 1839 Act and guided the parents that the correct principle for deciding custody was the needs of the child rather than the rights of either parent. It suggests that Alice had right to stay in the king's court; the king and queen had no right to send her out. The fictional scenario is a severe mockery on attitude of humans towards politicalized laws. Alice knows the political strategy of the king, and so refuses the order with protest,

“Well, I sha'n’t go, at any rate,” said Alice: “besides, that’s not a regular rule: you invented it just now."

"It's the oldest rule in the book," said the King.

"Then it ought to be Number One," said Alice.

The King turned pale, and shut his note-book hastily. "Consider your verdict, " he said to the jury, in a low trembling voice. (12.1.2)

The King feels threatened by her large presence in the King's court, and, we know, he is the judge. He uses his authority and declares self-made law trying to make her leave the court, but she questions the law and authority. Such challenges to law and law-makers are very common and real practices in the court of justice.

\section{Legal Scenareo in Charles Dickens's Fiction}

Charles Dickens knew poverty; he knew prison. His father was in prison for a long time because he could not paid dues. In spite of poverty and difficulties, Dickens studied law and his knowledge of law is observed in his novels. He is often connected with his popular characters: David Copperfield, Philip Pimp, Esther Summerson and Little Dorrit, but he is also known for his lawyers in his novels like Vohles, Jaggers, Stryver, and Tulkinghorn. Study and profession through law inspired him to involve such characters in his novels. Bleak House, Great Expectations, A Tale of Two Cities, and 
Law and Literature: A Review of Interdisciplinary Literary Texts 84 other novels have such characters in law profession. In Bleak House, law and lawyers both are equally important. Awesome, pervasive, perplexing, unnerving presence of law in the novel shows interdisciplinary and interactive roles of law and literature. First chapter in Bleak House mentions some words of litigation such as procrastination, trickery, evasion, spoliation, and botheration. The nineteenth century novelist Charles Dickens had a good command over the legal words.

Tulkinghorn in Bleak House is a lawyer highest in ranking and with the professional success. Many lawyers are there in the novel but he is highly admired. He is Sir Leicester Dedlock's lawyer. Dedlock and his wife both praise their lawyer for his distinct character. The lady is afraid of Tulkinghorn for, in her opinion, he is "Not a friend. One who is too passionless to be either. He is Sir Leicester Dedlock's lawyer; mechanically faithful without attachment, and very jealous of the profit, privilege and reputation of being master of the mysteries of great houses" (Sharma 36). She comments on his character further saying that "He is indifferent to everything but his calling. His calling is the acquisition of secrets and the holding possession of such power as they give him, with no sharer or opponent in it" (Sharma 36). Dedlock remarks, "He is, of course, handsomely paid, and he associates almost on a footing of equality with the highest society" (Sharma 40).

Jaggers is a lawyer in Great Expectations. He is Dickens's best-known lawyer entangled between his profession and moral life. He is a tough and hugely successful lawyer. He drives the legal netherworld of London to the accompaniment of everyone's awe. Sydney Carton is a lawyer in A Tale of Two Cities, who drinks too much. He is aimless, sad, troubled. Carton helps the lawyer Stryver to free Charles Darnay from the charge. Darnay has been accused of committing treason - a spy for France. Dickens' interest was in legal profession and law is everywhere in his novels.

\section{Legal Scenareo in Harper Lee's Fiction}

In Harper Lee's To Kill a Mockingbird, the middle part of the novel presents a court trial over a black man, named Tom Robinson, who has been accused for the rape of a white woman, Mayella Ewell, in racist Alabama in the 1930s. The child characters's father Atticus Finch is appointed to defend Robinson. The lawyer and his children suffer from the slurs and taunts of their neighbors. With his personal ethics and professional skills, he makes a strong defense and during the trial he proves that Robinson could not have raped Mayella. He convinces the court that her attacker was left-handed with two good arms, but Robinson had lost his left arm in a cotton-gin accident.

ATTICUS: Tom stands up. Let Miss Mayella have a good long look at you. Is this the man, Miss Mayella? 
Law and Literature: A Review of Interdisciplinary Literary Texts 85

Tom stands with his right hand on the back of the chair. His left hand is fully twelve inches shorter than his right and hangs dead at his side with a shriveled hand dangling at the end of the dead limb. JEM: Scout, Scout look! Reverend, he’s crippled! Sykes: He got it caught in a cotton gin, caught in Mr. Dolphus Raymond's cotton gin when he was a boy... like to bled to death... tore all the muscles loose from his bones. (7.60)

Beautiful, real cross-examination follows in the court in the same way as lawyers crossexamine the accused persons and witnesses. The lawyers, like Aticus, question in such a way that they can make the accused accept the crime. Bob is in similar trap here,

ATTICUS: Can you read and write?

BOB: I most positively can. How do you think I sign my relief checks?

Atticus brings out a pen and an envelope. Atticus gives Bob the pen and envelope.

ATTICUS: Would you write your name for us? Clearly now, so the jury can see you do it?

Mr. Ewell writes his name with his left hand.

BOB: What's so interestin'?

JUDGE: You're left-handed, Mr. Ewell.

Bob turns to the jury.

Atticus Finch, with his logics and cross-examination of witnesses and opposition, proves that Robinson was innocent, but the racial judge convicts him for the rape. A lawyer would like to read the whole court scene to develop the professional skill. They have got Bob produce the statement that he could "use one hand good as the other".

\section{Legal Scenareo in Shakespeare's Plays}

Did Shakespeare study law? Malissa Sarnicke asks the question in JurisMagazine blog post. Shakespeare is the greatest dramatist of all time. He was an English playwright, poet, and actor who published approximately 37 plays and 154 sonnets in his lifetime. However, there is controversy over his literary legacy, and his use of advanced legal terminology within his plays has been a subject of debate (Sarnicke). She is much amused to see legal humor into his plays. She quotes the dialogue between Touchstone and Corin from Act 3, Scene 2 of As You Like It:

TOUCHSTONE: Wast ever in court, shepherd?

CORIN: No, truly.

TOUCHSTONE: Then thou art damned.

CORIN: Nay, I hope. 
Law and Literature: A Review of Interdisciplinary Literary Texts 86

TOUCHSTONE: Truly, thou art damned like an ill-roasted egg, all on one side.

CORIN: For not being at court? Your reason?

TOUCHSTONE: Why, if thou never wast at court, thou never sawest good manners; if thou never sawest good manners, then thy manners must be wicked; and wickedness is sin, and sin is damnation. Thou art in a parlous state, shepherd. (As You Like It 3.2.256)

Shakespeare uses legal terms frequently in his plays and that has puzzled not only Sarnicke but also many other people. There is never ending debate over his education and knowledge of law. Shakespeare was a learned man and it has been examined and justified in Cushman K. Davis's book of 1883, called The Law in Shakespeare, critically analyzing many plays of the greatest dramatist of all time. Davis says that Shakespeare was more addicted to the employment of legal nomenclature than any English writer (excepting, of course, the jurists) is incontestable (3). Many plays have technically legal words and expressions that lawyers know. Dialogues contain legal terminology, documentations and cross-examinations.

Who by a seale compact, well ratified by law

And heraldrie, did forfeit with his life all those

His lands which he stood seazed of to the conqueror,

Against the which a moiety competent

Was gaged by our king. (Hamlet 1.1.6)

Seale compact (contract), ratified (approved with agreement and signature), forfeit (seize), moiety (part or portion divided) are some legal terms used in this extract. This dialogue from Horatio is all about valid legal document by which King of Fortinbras, King of Norway, had surrendered all his territories to dead King Hamlet.

HAM. There's another: why may not that be the skull of a lawyer? Where be his quiddities now, his quillets, his cases, his tenures, and his tricks? why does he suffer this rude knave now to knock him about the sconce with a dirty shovel, and will not tell him of his action of battery? Hum! This fellow might be in's time a great buyer of land, with his statutes, his recognizances, his fines, his double vouchers, his recoveries: is this the fine of his fines, and the recovery of his recoveries, to have his fine pate full of fine dirt? will his vouchers vouch him no more of his purchases, and double ones too, than the length and breadth of a pair of indentures ? The very conveyances of his lands will hardly lie in this box; and must the inheritor himself have no more, ha? (Hamlet 5.1.125) 
Law and Literature: A Review of Interdisciplinary Literary Texts 87

The dialogue contains the skull of a lawyer, quiddities, quillets, cases, tenures, and tricks, buyer of land, statutes, recognizances, fines, vouchers, recoveries, indentures, inheritor, and conveyances of lands. Hamlet's words in the dialogue are legal in nature and Shakespeare's contribution in the plays with his knowledge of law is incredible. Shakespeare was genius, a man of learning and knowledge in every area of human life. The Merchant of Venice is most quoted for its court scene, pleading by Portia who disguises herself as a man, an apprentice of a lawyer Balthazar, her wits, eloquence, and confidence, and cross-examination in the court. Her finding of loopholes and applying her rhetorical arguments during the pleading can persuade everyone to believe that Shakespeare had much skill and command over legal procedurals. Portia sees a loophole in the bond made between Shylock and Antonio and takes advantage of this and argues that the bond mentions a pound of flesh but not a single drop of blood. They know well that Shylock could not take the flesh from Antonio without drain of blood. Neither Shylock was ready to lose his property on Christian name. Thus Portia saves Antonio's life.

The case is proceeded by Cleverly Portia, with all assertive remarks, and leading Shylock into his own judgement, as if he were a child, like many clients in a case,

POR. A pound of that same merchant's flesh is thine; The court awards it, and the law doth give it.

SHY. Most rightful judge!

POR. And you must cut this flesh from off his breast; The law allows it, and the court awards it.

SHY. Most learned judge!_-A sentence; come, prepare. (The Merchant of Venice 4.1.159)

Shylock praises law, judge, and justice. He is excitedly ready to cut the flesh, but Portia suddenly changes her words and tactics; it was not easy for Shylock to understand the lawyer's intention:

POR. Tarry a little:- - there is something else.-

This bond doth give thee here no jot of blood;

The words expressly are a pound of flesh;

Take then thy bond, take thou thy pound of flesh;

But, in the cutting it, if thou dost shed

One drop of Christian blood, thy lands and goods

Are, by the laws of Venice, confiscate

Unto the state of Venice. (The Merchant of Venice 4.1.159)

The contract gives Shylock "a pound of flesh" but "no jot of blood”. Laws of Venice will confiscate his lands and goods to the state of Venice if he sheds even one drop of Christian blood, that of Antonio. Shylock is puzzled- 
Law and Literature: A Review of Interdisciplinary Literary Texts 88

SHY. Is that the law?

POR. Thyself shall see the act;

For, as thou urgest justice, be assur'd

Thou shalt have justice more than thou desir'st. (The Merchant of

Venice 4.1.159)

Law and act are synonyms but Portia might have given two meanings from 'act'- law and action, to be taken by them for justice. Shylock is still determined to get his money back;

SHY. I take this offer then;- - pay the bond thrice

And let the Christian go.

BASS. Here is the money.

POR. The Jew shall have all justice; — soft! —no haste; -

He shall have nothing but the penalty. (The Merchant of Venice

4.1.159)

Certainly, a Philadelphia lawyer Portia knows well how she has to move to case ahead and does not intend to let him go so easily;

POR. Therefore, prepare thee to cut off the flesh.

Shed thou no blood; nor cut thou less nor more,

But just a pound of flesh; If thou tak'st more,

Or less than a just pound,--be it but so much

As makes it light, or heavy, in the substance,

Or the division of the twentieth part

Of one poor scruple; nay, if the scale do turn

But in the estimation of a hair,-

Thou diest, and all thy goods are confiscate. (The Merchant of

Venice 4.1.160)

Law has power. Legal words have power. Portia argues in the court with legal language, and frightens him to his death;

POR. Why doth the Jew pause? take thy forfeiture.

SHY. Give me my principal and let me go. (The Merchant of Venice

4.1.160)

Bassanio, being a client with a common mind, is ready to pay, but Portia persists in her arguments and claims;

BASS. I have it ready for thee; here it is.

POR. He hath refused it in the open court;

He shall have merely justice, and his bond. (The Merchant of Venice

4.1.160) 
Law and Literature: A Review of Interdisciplinary Literary Texts 89

Shylock is a businessman, not a man of law. He is really very confused and frightened, and losing his ground;

SHY. Shall I not have barely my principal?

POR. Thou shalt have nothing but the forfeiture,

To be so taken at thy peril, Jew.

SHY. Why then the devil give him good of it;

I'll stay no longer question. (The Merchant of Venice 4.1.160)

Shylock is finally lost and he wishes to lose his principal and not to ask any more questions. This play is categorised as a tragicomedy for the same reason that, in spite of the bond and money that he was by all rights to receive, he loses bond, money and everything that he had intended (flesh!) Only a Philadelphia lawyer can do that with magic of legal rhetoric and tactics and Portia did that cleverly.We have thus a wonderful observation and study of law in literature.

The literary texts and legal contents in those texts mentioned above in analysis prove that literature and law have interdisciplinary and interactive relationship and roles. If we wish to read such literary texts with legal acts, we will find many of them available. Kafka's Last Trial is still popular among critiques and readers for the complex relationship between law and literature, with legal prosecution over the claims of Kafka'a legacy. Empty Justice: One Hundred Years of Law, Literature and Philosophy by Melainie Williams deals with existential, feminist and normative perspective in literary jurisprudence all through novels (xix).

\section{Conclusion}

Law and literature have distinctly different and separate areas of study. Nevertheless, literature and law have been closely connected throughout history of human civilization. Fiction and plays have narrative and interactive texts related to laws. Dramatic plays of legal scenes, court scenes, and examinations and cross-examinations show realistic scenes in literary texts. Literature and laws are originated and developed from the same culture. They have common norms and trends regarding conflicts, decisions, and justice. Linguistic creativity is central to the law, and legal creativity is seen in literature. Legal norms of good and bad conduct, of right and wrong, of rewards and punishment, are reflected or subverted in literature's engagement with questions of law and justice. Law seeks to regulate creative expression, while literary texts critique and sometimes openly resist the law. However, both these are subject to public interest of study. Research and study need to be elicited in both areas and students of law should study literature and students of literature should show their interest in laws so that students of both disciplines can engage in literary and legal creativity. Law and literature both make critical and creative mind of people. 
Law and Literature: A Review of Interdisciplinary Literary Texts 90

\section{Works Cited}

Balint, Benjamin. Kafka's Last Trial. W. W. Norton \& Company, 2018.

Carroll, Lewis. Alice's Adventures in Wonderland. Candlewick, 2003.

Coles, Robert. "Charles Dickens and the Law." Virginia Quarterly Review, vol. 59, no.

4, 1983, pp. 564-586. www.vqronline.org/essay/charles-dickens-and-law.

Cooper, Heather Lee. "Upstaging Uncle Tom's Cabin: African American Representations of Slavery before and after the Civil War." PhD thesis. U of Iowa, 2017.

Davis, Cushman K. The Law in Shakespeare. St. Paul, West Publishing Company Ltd., 1884.

Dickens, Charles. A Tale of Two Cities. Dover Publications, 1998.

Dickens, Charles. Great Expectations. CreateSpace, 2014.

Dickens, Charles. Bleak House. Penguine Classics, 2003.

Dolin, Kieran. A Critical Introduction to Law and Literature. Cambridge UP, 2007.

Dostoievsky, Feodor. The Brothers Karamazov. Translated by Constance Garnett. BOOK XII, The Lowell Press, 1912, pp. 845-997.

Gemmette, Elizabeth Villiers. Law in Literature: Legal Themes in Short Stories. Praeger Publishers, 1992.

Kalsem, Kristin B. "Alice in Legal Wonderland: A Cross-Examination of Gender, Race and Empire in Victorian Law and Literature.” Harvard Women's Law Journal, vol. 24, 2001, p. 221.

Lee, Harper. To Kill A Mockingbird. Grand Central Publishing, 1988.

Little, Gavin. "Literature and Legal History: Analyzing Methodology.” The

Entertainment and Sports Law Journal, vol. 3, no. 2, 2005, p. 4.

DOI./entsportslawjournal.com/article/10.16997/eslj.114/

Posner, Richard A. Law and Literature. $3^{\text {rd }}$ ed., Harvard UP, 2009.

Sarnicke, Melissa. Did He or Didn’t He: Did Shakespeare Study Law? JurisMagazine, Juris Blog, 2015.

Shakespeare, William. The Merchant of Venice. Cambridge UP, 2004.

- - -. Hamlet. Bantam Books, 1980.

- - -. As You Like It. Cambridge UP, 2003.

Sharma, G. K. "Administration of Justice in Ancient India with special Reference to Valmiki Ramayana and Tulsidas Ramcharitmanas.” PhD thesis. Jiwaji U, 2017.

Stowe, Harriet Beecher. Uncle Tom's Cabin. John P. Jewett and Company, 1852.

Weisberg, Richard. "Family Feud: A Response to Robert Weisberg on Law and Literature." Yale Journal of Law and the Humanities, vol. 1, no. 1, 1989, pp. 6977. www.digitalcommons.law.yale.edu./yjlh/vol1/iss1/5//

Williams, Melainie. Empty Justice: One Hundred Years of Law, Literature and Philosophy. Routledge, 2009. 